Journal of Business and Management Research

ISSN: 2382-5219(Print); 2467-9267(Online)

July 2017, Vol.2, No.1 \& 2, pp.52-65

(C) 2017 Kathmandu University

School of Management

DOI: http://dx.doi.org/10.3126/jbmr.v2i1-2.18151

\title{
Components of Celebrity Endorsement Affecting Brand Loyalty of Nepali Customers
}

\author{
Rojan Baniya* \\ School of Management, Kathmandu University, Lalitpur, Nepal
}

\begin{abstract}
This study investigates the direct effect of components of celebrity endorsement (physical attractiveness, source creditability and celebrity brand matchup) on brand loyalty (attitudinal loyalty and behavioral loyalty). 220 general customers of branded products participated in the study. Multiple regression analyses were conducted to test hypotheses. Our result shows that physical attractiveness, source credibility expertise and celebrity brand match up has positive impact on developing attitude towards the brand. However, only physical attractiveness and celebrity brand matchup are associated with purchase intention. Practical and research implications of the findings are discussed and directions for future research are suggested.
\end{abstract}

Keywords: Physical attractiveness, source creditability, trustworthiness, celebrity brand match-up, attitude towards brands, purchase intention

\section{Introduction}

Using celebrity endorsement to promote goods and services has become an established approach in many parts of the world. With the rapid invasion of electronic communication media in almost every home in the recent years, the use of celebrities has become even more popular. Renowned endorsers appear in approximately 25 percent of all genres of television commercials to boost and promote different products and brands, and data shows that roughly 10 percent of advertisers' budget is disbursed on employing celebrities (White, Goddard, \& Wilbur, 2009). With such strong importance, managers essentially need to determine ramification of a particular sponsorship (like celebrity endorsement) on different aspects of a brand's conduct like brand loyalty (Aaker, 1991; Keller, 2008).

The importance of celebrity endorsement has been well recognized and well respected in modern day marketing. Celebrity endorsement advertising has become a major feature of modern day marketing, which can be proved by the amount of money invested in celebrity endorsement (McCracken, 1989; Keller, 2008). A celebrity endorser is "any individual who enjoys public recognition and who uses this recognition on behalf of a consumer good by appearing with it in an advertisement" (McCracken, 1989, p. 310). The definition of the term celebrity has expanded a lot in current context. In previous time, mostly a movie star, TV star or a singer used to be labeled celebrity, but in real and current context, any individual who is successful and eminent in any discipline can be attributed into the group of celebrity (McCracken, 1989).

* Author Email: rojan@kusom.edu.np 
In both the western and eastern parts of the world, popularity of celebrity endorsements has soared due to a multitude of benefits companies have spotted by employing this form of advertisement. Due to explosion of media and information technology, today's media is severely cluttered (Nelson-Field, Riebe, \& Sharp, 2013). Day by day, it is becoming difficult for marketing managers to get customer's attention, and they are looking for celebrities to grab customer's attention with better opportunity to communicate their message to customers (Erdogan, Baker, \&Tagg, 2001). There are other benefits of using celebrity. For example, it helps viewers to remember and recall message of advertisement and brand (Agrawal \& Kamakura, 1995; Erdogan, 1999; Friedman \& Friedman, 1979; Misra \& Beatty, 1990). Celebrity endorsements are worthwhile investments as they bring quick memorability, recall and recognition, and direct client connection with the audience (Choudhary \& Sharma, 2015). Also, celebrities impart their own remarkable images to the advertisement and its associated brand, and can generate, magnify, and improvise brand image (Erdogan, 1999). From these one can conclude that celebrity endorsement helps products, services, and brands they represent.

Hofstede's $(1980,1983,1991)$ typology of culture presents a robust framework to evaluate crosscultural differences. These dimensions are individualism/collectivism, power distance, uncertainty avoidance, and masculinity/femininity. Nepal has high uncertainty avoidance, enjoys collectivism, low masculinity, and has high power distance (Dissanayake \& Semasinghe, 2015). On the contrary, English speaking western countries are low on power distance, low on uncertainty avoidance, enjoy individualism, moderately high on masculinity, and are short term oriented (Hofstede, 2011). Clearly, the typology of culture varies across cultures. So does the effectiveness of celebrity endorsement. A study showed that South Korea with a high power distance and a high uncertainty avoidance culture witnesses a higher share of celebrity endorsers than those in the US with a low power distance and a low uncertainty avoidance culture (Paek, 2005). This illustrates celerity endorsement studies in other cultural contexts cannot be generalized for Nepal with its own unique cultural dimensions. This study intends to contextualize the effectiveness of celebrity endorsement in unique Nepali cultural context.

With several studies on celebrity endorsement focusing on advanced economies, very few of such research works have been conducted in developing countries. This has resulted in a situation of literature gap and the assumption that the consumer behavioral patterns in these nations are just reflection of ones in the developed economy (Oyeniyi, 2014). One must not forget that research in recent years have demonstrated that ubiquitous generality of many marketing models may not hold (Mooij \& Hofstede, 2010). Additionally, culture remains an important determinant of consumer behavior (Aaker \& Lee, 2001; Farley \& Lehman, 1994). Due to these cultural differences, the way in which components of celebrity endorsement, i.e. physical attractiveness, source credibility, and celebrity matchup, affect in brand loyalty may be different in western and eastern cultures. Furthermore, celebrities enhance customers' attitudes regarding brands and products, but its contribution to generate repeat purchase intention as well as brand loyalty is not so clear (Byrne, Whitehead \& Breen, 2003).

This study, in part, is an effort to bridge this gap and explore the relevance and effect of celebrity endorsement in developing countries like Nepal. Hofstede's $(1980,2001)$ work shows the effect of culture in various marketing models, thus making it necessary to test the theories across culture. This study attempts to further endorse the relationship between components of celebrity endorsement and loyalty. There is serious paucity of research work in developing countries regarding celebrity endorsement, despite the fact of them being recognized as a prospective market for celebrity endorsed products. Most of the studies have been country specific like in India (Jain, 2011) and Nigeria (Oyeniyi, 
2014) leaving room to extend it to other national contexts. This study presents a new perspective of Nepali consumers about celebrity endorsement.

\section{Theoretical Framework and Research Hypotheses}

Given the amount of cost associated with celebrity endorsement, it is highly critical for a marketing manager to know whether it garners the desired effect or not. Although research findings are unclear about the power of celebrities to spawn genuine purchase behavior, documents reveal affirmative impact on economic returns of sponsoring companies (e.g., Agarwal \& Kamakura, 1995; Chung, Derdenger, \& Srinivasan, 2013; Elberse \& Verleun, 2012; Mathur, Mathur, \& Rangan, 1997). Amidst debate about productiveness of using celebrity endorsers, there is no doubt that celebrity endorsers are way more effective than non-celebrity endorsers in generating desirable outcomes provided that celebrities' public persona align to that of product and target audiences (Erdogan, 1999). Thus, marketers can choose to use celebrity endorsers instead of non-celebrity endorsers if their public guise is congruent to customers.

On the contrary, companies can never be fully assured about their substantial investment in celebrity endorsers. Once celebrities are associated with products or brands, brand equities of celebrities themselves are connected with them. If the celebrities receive negative publicity (high-profile scandals such as Michael Jackson, Kate Moss, and O.J. Simpson), it will greatly reduce the brand equity of the product as well, and the troublesome part is that companies have no control in lives of these celebrities (Busler, 2002; Erdogen 1999; Till \& Shimp, 1998. Also, customers consistently try to judge if celebrities themselves use product or not before endorsing; if found negative, the effect of celebrity endorsement might reduce (Jain, 2008). In these lights, the risks of using celebrity endorsement cannot be overlooked. Marketers need to remain more alert in selection and deployment of celebrity endorsement for their hardbuilt brands.

Academicians have appointed study of cross-cultural difference as their central topic in their marketing literature (Zhang, Lam \& Connaughton., 2003). It is well established that cultural differences are a vital feature in determining the various comprehension in attitudes, cognitions, beliefs, and values (Hofstede \& Bond, 1983). In this entry, advertisers should not fail to take into account cultural differences, and more specifically, celebrity endorsers should be assessed in the light of cultural meaning they possess. (Choi, Lee, \& Kim, 2005; Pornpitakpan, 1997; Till \& Shimp, 1998). This give rise to an important fact that the effect of celebrity endorsers is likely to vary across cultural settings. Thus, this

study has tremendous value in confirming or disconfirming to the established effects of celebrity endorsers in western cultural settings.

Brand loyalty comprises both attitudinal loyalty and behavioral loyalty. The components of the brand endorsement should ultimately lead to brand loyalty both in behavioral and attitudinal terms. That is how the investment made in celebrity can be justified as to garner the bottom line that advertisers are looking for from it.

\section{Brand Loyalty}

Maintaining and enhancing brand loyalty has been widely admitted as a core objective of marketing activities (Aaker, 1991; Baldinger \& Rubinson, 1996). In highly cited definition of brand loyalty, Aaker (1991, p. 25) expressed brand loyalty as "the degree of a consumer's emotional attachment to a brand and suggests that it has six dimensions: consumer willingness to repurchase, price premium, satisfaction 
rate, switching cost, preference over brand, and commitment to brand". This clearly shows the reason why the efforts of marketer are to get the ultimate brand loyalty from its customers.

And to the researchers brand loyalty stands as a complex multi-dimensional construct (Dick \& Basu, 1994; Ha, 1998; Javalgi \& Moberg, 1997; Mellens, Dekimpe \& Steenkampe, 1996). Two distinct approaches to study brand loyalty, viz.: attitudinal approach (Guest, 1944) and behavioral approach (Cunnigham, 1956), have been taken, which is still widespread and accepted today. Noticeably, in the 90's, both attitudinal and behavioral dimensions of loyalty were recognized as important constructs (Baldinger \& Rubinson, 1996; Dick \& Basu, 1994). It has been suggested that marketers should take into account both attitudinal and behavioral loyalty to determine customers brand loyalty (Bennett \& Bove, 2002). A composite measure of attitudinal and behavioral loyalty is best for marketers.

\section{Attitude towards the Brand (Attitudinal Loyalty)}

The affective and cognitive parts of the brand loyalty are the main center of interest of attitudinal loyalty, which mainly measures brand preference of the customers (Gremler \& Brown, 1998; Mellens et al., 1996; Traylor, 1981). Consumers' fondness of specific products or service can be termed as attitudinal loyalty (Kumar \& Reinartz, 2006). The attitudinal modus operandi to loyalty puts emphasis on the importance of understanding the purchase driven experiences and further more amalgamate measures of attitude towards the object such as preference or liking (Pellemans, 1974; Ajzen \& Fishbein, 1980; Mellens et al., 1996), and commitment (Traylor, 1981; Foxall, 1987; Martin \& Goodell, 1991; Mellens et al., 1996). Thus, evidently, attitudinal loyalty contributes a lot in ensuring that customers procure the brand themselves, they will, by means of word-of-mouth, assist in creating a favorable statute of a business to others, which is critical to brand's prosperity.

Purchase Intention (Behavioral Loyalty)

Behavioral loyalty means consumers' repurchase behavioral or intension of specific brand from the available options (East, 1997; Ehrenberg, 1988, Russell-Bennett, 2007). It is a function of a favorable repeat purchase pattern (Bandyopadhyay \& Martell, 2007). A number of aspects are said to have an effect on the purchase intentions of the consumers; however, behavioral loyalty guarantees that customer loyalty is converted into actual purchase behaviors.

The refinement and upgradation of past researches on loyalty promulgate new proposition for evaluation of customer loyalty: (1) behavioral measurement, (2) attitudinal measurement, and (3) composite measurement (a combination of behavioral and attitudinal measurements) (Bowen \& Chen, 2001). The composite measurement provides coverage on both behavioral and attitudinal aspect of loyalty.

\section{Celebrity Endorsement}

Any distinct personality who is prosperous in the world of business, art, sports, entertainment, politics etc. but mostly TV star, movie star or musician can be known as a celebrity (McCracken, 1989). While endorsing, celebrity takes the form of an impersonal message source, with characteristics that include personal attributes like attractiveness, power, or credibility, and enable the endorsed to influence the consumer. As stated by Byrne et al. (2003), credibility refers to the knowledge, skill, and expertise related to the product/s, attractiveness refers to the likeability, familiarity, and similarity of the celebrity and power enables the endorser to bias the consumer. Most of the times, these are the reasons for using celebrity as an endorser of a brand. 
Celebrity selection for a product or service is always a challenge, and a critical decision. Since Aristotle's time, attempts have been made to recognize the decisive qualities of effective communicators (Giffin, 1967). An inevitable question is what type of celebrity endorser is effective - the ones who is attractive or the one who is considered trustworthy or the one who is expert or one should look for combination of all three. Looking at the investment that goes into celebrity endorsement, one should be careful to select celebrity endorser.

\section{Components of Celebrity Endorsement}

The study takes into considerations three most important components of celebrity endorsement physical attractiveness, source credibility comprising of trustworthiness and expertise and celebrity/brand match up.

Brand Loyalty and Physical Attractiveness: Endorsers' physical exhibits like personality, likeability, and similitude to the receiver, also known as physical attractiveness, in fact delivers social value of the message source to the receiving consumers (Solomon, 2002). Physical attractiveness is of utmost value because most studies have shown that a physically attractive source is actually able to assist attitude change (Joseph, 1982; Mills \& Harvey, 1972). Also, a good- looking celebrity can be utilized to endorse a product that would promote the attractiveness component (Kahle \& Homer, 1985). Television and print advertising commonly use physically attractive communicators to influence customers' attitudes and beliefs and they have proven to be successful (Ohanian, 1991). In all the studies, physical attractiveness has emerged out to be a pivotal component of celebrity endorsers, and consequently abundance of use of the same can be seen in promotion to induce loyalty.

Brand Loyalty and Source Credibility: In celebrity endorsement, the endorser communicates message with the target audience. Source credibility model manifests that the perceived level of expertise and trustworthiness that customers see in the endorser determines the effectiveness of a message (Sternthal \& Dholakia, 1978). If a person perceives truth in a piece of information, he or she sees it as credible. If the receiver is able to attribute genuineness and concreteness to the information received, accordingly they rate the information source or transmitter of the communication in relation to the information (Hovland, Janis \& Kelley, 1953; Eisend, 2006). Thus, source credibility is another important component, as it helps customers make rational decisions, making a customer attached towards a brand ingraining loyalty.

Brand Loyalty and Trustworthiness: As defined by Erdogan (1999), trustworthiness refers to the confidence that audience exhibits in the informant for providing information in an unprejudiced and genuine manner. Trustworthiness indicates the honesty and integrity of the spokesperson; thus it can be defined as the degree customers perceive endorsers to be believable, honest, and dependable. Advertisers are most likely to select those endorsers who are greater proportion in this aspect (Shimp, 2007). Trustworthiness contributes to source credibility, which in turns contributes to loyalty.

Brand Loyalty and Expertise: Expertise is the extent to which a message communicator is trusted to be source of valid assertions (Hovland et al., 1953). Generally, endorsers occupy the position of experts in the eyes of the customer, if the endorser is perceived to be knowledgeable, skillful, and experienced about the product and services. Expert endorsers always perform in the positive side and are beneficial because they strengthen brand recall and positively influence customer's buying intention (Erdogan, 1999). Like trustworthiness, expertise also contributes to source credibility of an endorser.

Brand Loyalty and Celebrity/Brand Match-up: Companies need to think hard before selecting celebrity to represent their brand about the congruence or celebrity/brand match-up. Celebrity/Brand 
Congruency hypothesis states that there needs to be a match between the celebrity personality characteristics and brand attributes. And the degree of successful matchup can be ascertained by fitness between the brand and the celebrity (Erdogan, 1999). In most exact terms, this congruence helps in imparting of meaning from one to another, which is one of the key purposes of advertising (Misra \& Beatty, 1990; Kamins \& Gupta, 1994; Lynch \& Schuler, 1994).

Also, studies show further importance of celebrity/brand match-up. The congruency also makes the advertisement more influential and credible (Michael, 1989). Previous studies have shown, that more congruent celebrity/brand pair leads to the positive response to advertising in terms of attitude and purchasing intent (Kahle \& Homer, 1985; Kamins, 1990; Misra \& Beatty, 1990; Lynch \& Schuler, 1994; Erdogan \& Baker, 2000; Till \& Busler, 2000; Batra \& Homer, 2004).

Thus the hypotheses set for the study are:

H1a: Physical attractiveness is positively related to customer's attitude towards advertised brand.

H1b: Source credibility is positively related to customer's attitude towards advertised brand.

H1c: Celebrity brand match up are positively related to customer's attitude towards advertised brand.

$\mathrm{H} 2 \mathrm{a}$ : Physical attractiveness is positively related to purchase intention of the customers.

$\mathrm{H} 2 \mathrm{~b}$ : Source credibility is positively related to purchase intention of the customers.

H2c: Celebrity brand matchup is positively related to purchase intention of the customers.

The research model showing proposed interrelationships among different variables is shown in Figure 1.

Celebrity Endorsement

Brand Loyalty

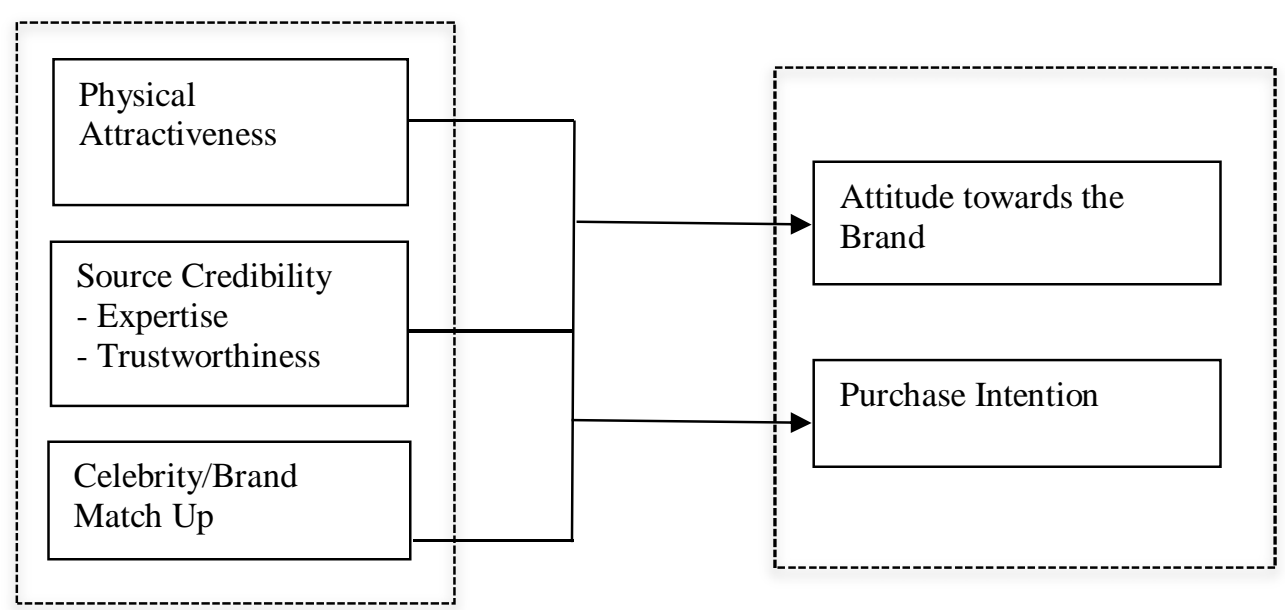

Figure 1. Research Model 


\section{Method}

\section{Sample and Procedure}

300 questionnaires were distributed to the general consumers residing in Kathmandu valley. Altogether, 220 questionnaires were returned and were found usable. The study setting for this study is non-contrived general setting. The subjects involved are the regular customers of product and services who are exposed to celebrity endorsement. A simple stimulus was developed in form of a section in the questionnaire where 'name of the celebrity' and advertisement that celebrity appeared in, were listed. Thirteen advertisements regularly shown in media with celebrities name alongside were listed. The respondents were selected conveniently based on their exposure to advertisements.

Ethical standard guidelines were followed during data collection, where the participant remained unanimous and the participation was voluntary. Also, data was collected with informed consent by independent third party. This way a special attention was given to protect respondent anonymity and reducing evaluation apprehension. Pre-testing of the questionnaire was done to test the clarity of the questionnaire, suitability to the participants, to assess the needed time, the possible obstacle that could arise while responding to the survey. This way, in this study an attempt was made to reduce method biases through the careful construction of the items themselves.

Fifty six percent respondents of the study were male. Eighty five percent of the respondents were of age 16-30, 12 percent of 31-45, and the remaining above $45.85 \%$ of the respondents had bachelor and masters level education. Approximately 57 percent respondents earn below 20 thousands monthly, 28 percent earned above 20 thousands to 50 thousands, and the remaining respondents earned above 50 thousands.

\section{Measures}

Already validated scales were used for capturing study variables. The instrument used for data collection was developed by Ohanian (1990) on five point Likert scale for his research work about Celebrity Endorsement. In his research, three dimensions namely celebrity attractiveness, trustworthiness, expertise were accessed by five items and the Purchase Intention by three items. Thus, the survey questions used here were adopted from previous studies (Ohanian, 1990; Kamins \& Gupta, 1994; Khale \& Homer, 1985).

Chronbach's alpha was used to assess the reliability of each scale used. The outcome shows that the alpha coefficient of the scales ranged from .695 (expertise) to .821 (physical attractiveness).

\section{Results}

Pearson correlation coefficients between study variables as well as their mean, standard deviation, and internal consistency reliability (Cronbach's alpha) are shown in the Table 1.

The result indicates that all the relationships between different study variables are significant and in the expected directions. As said by Cohen (1983) any value ranging from 0.30 to 0.49 in the Pearson correlation analysis, is termed as having a medium strength in the relationship. Most of the relationships except between SCT and AB have at least medium strength. But, these correlation analyses, as suggested by several management researchers are not robust enough to test the proposed hypotheses. Therefore, 
regression equations were estimated to assess the relationships between $\mathrm{AB}$ and $\mathrm{PI}$ and other dependent variables. The results of regression analyses are shown in Table 2.

Table 1

Mean, Standard Deviation, Correlation Matrix and Cronbach's Alpha

\begin{tabular}{|c|c|c|c|c|c|c|c|c|c|}
\hline & & Mean & SD & 1 & 2 & 3 & 4 & 5 & 6 \\
\hline 1 & PA & 3.34 & 0.81 & .82 & & & & & \\
\hline 2 & SCT & 2.78 & 0.88 & $.49^{* *}$ & .74 & & & & \\
\hline 3 & SCE & 2.57 & 0.85 & $.32 * *$ & $.58^{* *}$ & .69 & & & \\
\hline 4 & $\mathrm{CBM}$ & 2.64 & 0.70 & $.36^{* *}$ & $.53^{* *}$ & $.51^{* *}$ & .71 & & \\
\hline 5 & $\mathrm{AB}$ & 2.79 & 0.72 & $.37 * *$ & $.29 * *$ & $.46^{* *}$ & $.44 * *$ & .82 & \\
\hline 6 & PI & 2.44 & 0.76 & $.44^{* *}$ & $.43^{* *}$ & $.33^{* *}$ & $.51^{* *}$ & $.56^{* *}$ & .71 \\
\hline
\end{tabular}

Note: $\quad * * p<.01$

PA - Physical Attractiveness, SCT - Source Credibility Trustworthiness, SCE - Source Credibility Expertise, CBM - Celebrity Brand Match-up, AB - Attitude Towards Brand, PIPurchase Intent

Cronbach's alpha shown in diagonal

Relationships of Celebrity Endorsement with Attitude towards Brand and Purchase Intention

A regression analysis was carried out to ascertain the strength of relationship of physical attractiveness, source creditability trust, source creditability expertise, and celebrity/brand match up with attitude towards brands. The regression results revealed that regression model is significant $(F=22.12, p<.01)$ and $28.7 \%$ variance in attitude towards the brand is explained by the independent variables of the regression model $\left(R^{2}=.287\right)$. Except source credibility trustworthiness, all other variables were found to be significant predictors of attitude towards brands.

Table 2

Multiple Regression Analyses Results

\begin{tabular}{|c|c|c|}
\hline & \multicolumn{2}{|c|}{ Dependent Variable } \\
\hline Predictors & $\mathrm{AB}$ & PI \\
\hline PA & $.25^{* *}$ & $.24 * *$ \\
\hline SCT & -.12 & -.09 \\
\hline SCE & $.29 * *$ & $.02 *$ \\
\hline CBM & $.26 * *$ & $.42 * *$ \\
\hline$R^{2}$ & .28 & .38 \\
\hline$F$ & $22.12 * *$ & $32.47 * *$ \\
\hline
\end{tabular}

Note: $* p<.05, * * p<.01$

PA - Physical Attractiveness, SCT - Source Credibility Trustworthiness, SCE - Source Credibility Expertise, CBM - Celebrity Brand Match-up, AB - Attitude Towards Brand, PI - Purchase Intention

The strength of relationship of physical attractiveness, source creditability trust, source creditability expertise, and celebrity/brand match up with purchase intention was assessed using another regression 
analysis. The regression model is significant $(F=32.47, p<.01)$ and $38.6 \%$ variance in purchase intention is elucidated by the chosen independent variables of the regression model. The regression result also reveals that except credibility trustworthiness, all other variables are significant predictors of purchase intentions.

\section{Discussion}

This study examined the influence of celebrity endorsement elements (physical attractiveness, source creditability trustworthiness, source credibility expertise, and celebrity brand match up) on customers' attitudinal and behavioral loyalty (attitude towards a brand and purchase intention). It is widely accepted that celebrities are an effective and profitable marketing element. The persuasive and convincing technique of celebrity is derived from the attributes attached with celebrity, which is the reason for endorsement to more effective (Erdogan, 1999). Such attributes have been assessed for attractiveness, source credibility, and brand celebrity congruence.

The study shows physical attractiveness of celebrities has positive impact on both attitude towards brands and purchase intention. This is consistent with the findings of Biswas, Hussain, \& ODonnell (2009) that the reasons for recalling celebrities included popularity, status symbol, attractiveness and glamour, likeability and recall value or familiarity of the celebrities. Also celebrities are considered to bring attention towards advertisement due to their likeability and attractiveness (Erdogan et al., 2001).

Another study showed that physical attractiveness has positive impact on Indian customers but negative impact on Pakistani customers (Hassan \& Ahmed, 2014). The three main factors - similarity, familiarity and liking for an endorser - are the antecedents of the effectiveness of a message as explained by Source Attractiveness Model (McGuire, 1985). In the Asian context, celebrities are ideals; people follow their life stories and life styles and they like them to the core. Thus, the physical attractiveness component of celebrity endorsement is important and advertisers need to take into consideration the physical attractiveness of celebrities while selecting them.

The study shows that source creditability trustworthiness was not significant in explaining attitude towards brands, however source credibility expertise was. In case of purchase intention both were found to be non-significant. The Source Credibility Model proposes that the effectiveness of a message depends on perceived level of expertise and trustworthiness in an endorser (Ohanian, 1991). Maddux and Rogers (1980) reckoned that a celebrity endorser high in expertise leads to a more positive perception towards the brand. However, the fact is that most of the celebrities in Asian context are movie stars and sportsmen who lack expertise in the subjects endorsed. Thus the finding is consistent that source credibility trustworthiness in the celebrity endorser lacks. In recent trends, the experts (e.g. doctors, engineers etc.) are also used in advertisements. This may be the reason that expertise was significant to create attitude towards brands.

The study shows that the brand and celebrity matchup have significant and positive impact on attitudinal and behavioral loyalty. The finding is consistent with previous study that a high congruency between the celebrity and the brand will encourage the furtherance of friendship between the brand and the endorser (Kamins, 1990). This leads to good association. Previous studies show that celebrity product congruency technique is employed to promote brands, and this trend is highly evident in cosmetics brands. A higher degree of congruency could enhance the effect of the celebrity-endorsed brand hence establishing the genuineness of the brand (Kamins, 1990). Thus the marketers have to spend good deal of time, searching for appropriate celebrity based on their brand and brand image. 
As the study supports the direct effect of physical attractiveness and celebrity brand match up on both behavioral and attitudinal loyalty of customers, the findings can have significant practical implications for marketing managers. Celebrity endorsement can be considered as one of the solutions for increasing attitudinal and behavioral loyalty among the customers. The insignificance of source credibility indicates that this component of celebrity endorsement may not be effective, thus may not be appropriate to be evoked. Marketing managers in organizations however needs to exploit both physical attractiveness and brand celebrity match up aspects of celebrity endorsement to generate loyalty. This study provides a clear guidance to marketers regarding the relevance and effect of celebrity endorsement in developing countries like Nepal. It confirms to the importance of celebrity endorsement in Nepal as a vital tool of promotion.

\section{Limitations and Suggestions for Future Research}

This study has several limitations that need to be addressed in future research. All the study variables were captured from self-reported measures and therefore self-report bias cannot be ruled out. Nonetheless, the findings of this study are in line with the findings of the studies carried out in the different cultural contexts suggesting that components of celebrity endorsement have effect on customer loyalty.

This study may be replicated with samples from various other developing nations so as to validate the findings of present study. Also, the result of the study being positive, other areas of research like impact and efficacy of media source, type of celebrity and their impacts etc. can be conducted in developing nation. Furthermore, the convenient sampling was used in the study; future researches can use random sampling. Also, higher robust statistical techniques other than regression like Structural Equation Modelling (SEM) can be used in future research.

\section{References}

Aaker, D. (1991). Managing brand equity: capitalizing on the value of a brand name. Free Press, New York.

Aaker, J., \& Lee, A. (2001)."I" seek pleasures and "We" avoid pains: The role of self- regulatory goals in information processing and persuasion. Journal of Consumer Research, 28(1), 33-49. http://dx.doi.org/10.1086/321946

Agarwal, J., \& Kamakura, W. A. (1995). The economic worth of celebrity endorsers: An event study analysis. Journal of Marketing, 59(3), 56-63. Retrieved from http://www.marketingpower.com

Ajzen, I., \& Fishbein, M. (1980). Understanding Attitudes and Predicting Social Behaviour. New Jersey: Prentice-Hall.

Baker, M. J., \& Churchill, G.A. Jr. (1977). The impact of physically attractive models on advertising evaluations. Journal of Marketing Research, Vol. 14, pp. 538-555.

Baldinger, A., \& Rubinson, J. (1996). Brand loyalty: the link between attitude and behavior. Journal of Advertising Research, 36(6), 22-34.

Bandyopadhyay, S., \& Martell, M. (2007). Does attitudinal loyalty influence behavioral loyalty? A theoretical and empirical study. Journal of Retailing and Consumer Services 14, 35-44. http://dx.doi.org/10.1016/j.jretconser.2006.03.002 
Batra, R., \& Homer, P.M.(2004). The situational impact of brand image beliefs. Journal of Consumer Psychology 14 (3), 318-330.

Bennett, R., \& Bove, L. (2002). Identifying the key issues for measuring loyalty. Australasian Journal of Market Research, 9(2). pp. 27-44.

Biswas, S., Hussain, M., \& O'Donnell, K. (2009). Celebrity endorsements in advertisements and consumer perceptions: a cross-cultural study. Journal of Global Marketing, vol. 22, no. 2, pp. 121137. http://dx.doi.org/10.1080/08911760902765940

Bowen, J.T., \& Chen, S.L. (2001). The relationship between customer loyalty and customer satisfaction. International Journal of Contemporary Hospitality Management 13(5), 213-217 http://dx.doi.org/10.1108/09596110110395893

Busler, M. (2002). Product differentiation, celebrity endorsements and the consumer's perception of quality (Doctoral dissertation, Drexel University)

Byrne, A., Whitehead, M., \& Breen, S. (2003). The naked truth of celebrity endorsement. British Food Journal, V 105 (4/5) pp. 288-296.

Choi, S. M., Lee, W. N., \& Kim, H. J. (2005). Lessons from the rich and famous: A cross-cultural comparison of celebrity endorsement in advertising. Journal of advertising, 34(2), 85-98. http://dx.doi.org/10.1080/00913367.2005.10639190

Choudhary, L., Sharma,A. (2015). An exploratory research on effectiveness of celebrity endorsement and its relation with brand recall in reference to the Indian context. Elk Asia Pacific Journal of Marketing and Retail Management, V 6 (1) http://dx.doi.org/10.16962/EAPJMRM/issn.2349$\underline{2317 / 2014}$

Chung, K. Y., Derdenger, T. P., \& Srinivasan, K. (2013). Economic value of celebrity endorsements:

Tiger Woods' impact on sales of Nike golf balls. Marketing Science, 32(2), 271-293. http://pubsonline.informs.org/doi/abs/10.1287/mksc.1120.0760Dick,

A. S., \& Basu, K. (1994). Consumer loyalty: towards an integrated conceptual approach. Journal of the Academy of Marketing Science, 22(2), 99-113. http://dx.doi.org/10.1177/0092070394222001

Dissanayake, D. M. N. S. W., \& Semasinghe, D. M. (2015). Is culture a restraining or a driving force for entrepreneurship in Sri Lanka?. African Journal of History and Culture, 7(1), 8-15.

East, R. (1997). Consumer Behaviour: Advances and Applications in Marketing. Hertfordshire: Prentice Hall.

Ehrenberg, A. S. C. (1988). Repeat-buying: facts, theory and applications. Charles Griffin \& Company Limited, London.

Eisend, M. (2006). Source credibility: dimensions in marketing communication-A generalized solution. Journal of Empirical Generalizations in Marketing Science, 10, 1-33.

Elberse, A., \& Verleun, J. (2012). The economic value of celebrity endorsements. Journal of Advertising Research, 52(2), 149-165. http://dx.doi.org/10.2501/JAR-52-2-149-165

Erdogan, B. Z. (1999). Celebrity endorsement: A literature review. Journal of Marketing Management, 15(4), 291-314. http://dx.doi.org/10.1362/026725799784870379

Erdogan B.Z. \& Baker, M.J. (2000). Towards a practitioner-based model of selecting celebrity endorsers. International Journal of Advertising, 19 (1), 25-42.

Erdogan, B. Z., Baker, M. J., \& Tagg, S. (2001). Selecting celebrity endorsers: the practitioner's perspective. Journal of Advertising Research, 41(3), 39-48. http://dx.doi.org/10.2501/JAR-41-3-39$\underline{48}$

Farley, J. U., \& Lehman, D. R. (1994) Cross-national 'laws' and differences in market response. Management Science, 40(1), 111-122. http://dx.doi.org/10.1287/mnsc.40.1.111 
Foxall, G. R. (1987). Radical behaviourism and consumer research: theoretical promise and empirical problems. International Journal of Research in Marketing, 4 (2), 111-129.

Friedman, H. H. \& Friedman, L. (1979). Endorser effectiveness by product type. Journal of Advertising Research, 19 (5), 63-71.

Giffin, K. (1967). The contribution of studies of source credibility to a theory of interpersonal trust in the communication process. Psychological Bulletin, 68 (2), 104-119.

Gremler, D. D., \& Brown, S. W. (1998). Service loyalty: antecedents, components and outcomes. American Marketing Association Winter Conference, 165-166.

Guest, L. P. (1944). A study of brand loyalty. Journal of Applied Psychology, 28, 16-27. http://dx.doi.org/10.1037/h0053554

Ha, C.L. (1998). The theory of reasoned action applied to brand loyalty. Journal of Product and Brand Management, 7 (1), 51-61. http://dx.doi.org/10.1108/10610429810209737

Hassan, S.R.U., \& Ahmed, R.J. (2014). Influence of celebrity endorsement on consumer purchase intention of existing products: a comparative study. Journal of Management Info, 4, (1), 1-23.

Hofstede, G., (1980). Culture's consequences: international differences in work-related values. Baverly Hills, CA: Sage Publications.

Hofstede, G. (1983). National cultures in four dimensions. International Studies of Management \& Organization, 13(1/2), 46-74.

Hofstede, G. (1991).Culture and organizations: Software of the mind. London: McGraw-Hill.

Hofstede, G. (2001).Culture's consequences: comparing values, behaviors, institutions and organizations across nations. Thousand Oaks, CA: Sage Publications.

Hofstede, G. (2011). Dimensionalizing cultures: The Hofstede model in context. Online readings in psychology and culture, 2(1), 8.

Hofstede, G., \& Bond, M. H. (1983). Hofstede's culture dimensions an independent validation using Rokeach's value survey. Journal of cross-cultural psychology, 15(4), 417-433. http://journals.sagepub.com/doi/abs/10.1177/0022002184015004003

Hovland, C.I., Janis, I. L., \& Kelley, H. H. (1953). Communication and Persuasion: Psychological Studies of Opinion Change, Yale University Press, New Haven, CO.

Javalgi, R.G., \& Moberg, C.R. (1997). Service loyalty: implications for service providers. The Journal of Services Marketing, 11 (3), 165-79.

Joseph, W. B. (1982). The credibility of physical attractive communications: a review. Journal of Advertising, 11(3), 15-24.

Kahle, L.R., \& Homer, P.M. (1985). Physical attractiveness of the celebrity endorser: A social adaptation perspective. Journal of Consumer Research-v11 (4). - pp. 954-961.

Kamins, M.A. (1990). An investigation into the 'match-up' hypothesis in celebrity advertising: when beauty may be only skin-deep. Journal of Advertising, 19(1,) 4-13. http://dx.doi.org/10.1080/00913367.1990.10673175

Kamins, M. A., \& Gupta, K. (1994). Congruence between spokesperson and product type: a match up hypothesis perspective. Psychology and Marketing 11 (6), 569-586. http://dx.doi.org/10.1002/mar.4220110605

Keller, K.L. (2008). Strategic Brand Management: Building, Measuring, and Managing Brand Equity (3rd edition), Upper Saddle River, NJ, Pearson Prentice Hall.

Kumar, V., \& Reinartz. W.J. (2006). Customer Relationship Management: A Databased Approach. New York: John Wiley. 
Lynch, J., \& Schuler, D.(1994). The match up effect of spokesperson and product congruency: a schema theory interpretation. Psychology and Marketing 11 (5), 417-445. http://dx.doi.org/10.1002/mar.4220110502

Maddux, J.E. \& Rogers, R.W. (1980). Effects of sources expertness, physical attractiveness and supporting arguments on persuasion: A case of brain over beauty. Journal of Personality and Social Psychology, 39(2), 235-244.

Martin, C. L., \& Goodell, P. W. (1991), Historical, descriptive and strategic perspectives on the construct of product commitment. European Journal of Marketing, 25 (1), 53-60.

Mathur, L. K., Mathur, I., \& Rangan, N. (1997). The wealth effects associated with a celebrity endorser: The Michael Jordan phenomenon. Journal of Advertising research, 37(3), 67-74.

McCracken, G. (1989). Who is the celebrity endorser? Cultural foundations of the endorsement process. Journal of Consumer Research, 16(3), 310-321. http://dx.doi.org/10.1086/209217

McGuire, W. J. (1985). Attitudes and attitude change. In G. Lindzey and E. Aronson (Eds.), Handbook of social psychology (3rd ed.), Volume II: Special fields and applications. New York: Random House.

Mellens, M., Dekimpe, M.G., \& Steenkampe, J. B. E. M. (1996). A review of brand-loyalty measures in marketing. Tijdschriftvoor Economie en Management, 41 (4), 507-533.

Michael, A. K. (1989). Celebrity and non-celebrity advertising in a two-sided context. Journal of Advertising Research 6(7), 34-42.

Mills, J., \& Harvey, J. (1972). Opinion change as a function of when information about the communicator is received and whether he is attractive or expert. Journal of Personality and Social Psychology, 21(1), 52.

Misra, S., \& Beatty, S. E. (1990). Celebrity spokesperson and brand congruence: an assessment of recall and affect. Journal of Business Research 21(2), 159-173. http://dx.doi.org/10.1016/01482963(90)90050-N

Mooij, De. M., \& Hofstede, G. (2010). The Hofstede model. International Journal of Advertising, 29(1), 85-110. http://dx.doi.org/10.2501/S026504870920104X

Nelson-Field, K., Riebe, E., \& Sharp, B. (2013). More Mutter About Clutter. Journal of Advertising Research, 53(2), 186-191. http://dx.doi.org/10.2501/JAR-53-2-186-191

Ohanian, R (1990) "Construction and validation of a scale to measure celebrity endorser's perceived expertise, trustworthiness, and attractiveness", Journal of Advertising, 19(3): 39: 52.

Ohanian, R. (1991). The impact of celebrity spokespersons' perceived image on consumers' intention to purchase. Journal of Advertising Research, 31(1), 46-54.

Oyeniyi, O. (2014). Celebrity endorsements and product performance: a study of Nigerian consumer markets. Management \& Marketing, XII (1), 41-50.

Paek, H. J. (2005). Understanding celebrity endorsers in cross-cultural contexts: A content analysis of South Korean and US newspaper advertising. Asian Journal of Communication, 15(2), 133-153.

Pellemans, P. A. (1974), Investigations on attitude and purchase intention towards the brand. Consumer Behaviour: Theory and Applications, U. Farley, Ed. Boston: Allyn \& Bacon, 115-129.

Pornpitakpan, C. (1997). The effect of cultural adaptation on perceived trustworthiness. Journal of Global Marketing, 11(3), 41-64. http://dx.doi.org/10.1300/J042v11n03_04

Russell-Bennett, R., McColl-Kennedy, J.R., Coote, L.V. (2007). Involvement, satisfaction and brand loyalty in a small business services setting. Journal of Business Research, 60(12), 1253-1260. http://dx.doi.org/10.1016/j.jbusres.2007.05.001

Shimp, T. A. (2008). Advertising, promotion, and other aspects of integrated marketing communications, Mason, Ohio: South Western Cengage Learning. 
Solomon, N. R. (2002) Consumer Behaviour: Buying Having and Being. 5th ed., New Jersey, Prentice Hall.

Sternthal, B., Dholakia, R., \& Leavitt. C. (1978). The persuasive effect of source credibility: a test of cognitive response analysis. The Journal of Consumer Research, 4 (4), 252-260. http://dx.doi.org/10.1086/268454

Suresh Jain, R. (2008). A study on the impact of celebrity endorsement on the Indian consumers purchase decision (MA dissertation). England: The University of Nottingham

Till B. D., \& Busler, M. (1998). Matching products with endorsers: attractiveness versus expertise. Journal of Consumer Marketing, 15 (6), 576-586. http://dx.doi.org/10.1108/07363769810241445

Till, B. D., \& Shimp, T. A. (1998). Endorsers in advertising: The case of negative celebrity information. Journal of advertising, 27(1), 67-82. http://dx.doi.org/10.1080/00913367.1998.10673543

Traylor, M. B. (1981). Product involvement and brand commitment. Journal of Advertising Research, 21 (6), 51-56.

White, D. W., Goddard, L., \& Wilbur, N. (2009). The effects of negative information transference in the celebrity endorsement relationship. International Journal of Retail and Distribution Management, 37(4), 322-335. http://dx.doi.org/10.1108/09590550910948556

Zhang, J. J., Lam, E. T., \& Connaughton, D. P. (2003). General market demand variables associated with professional sport consumption. International Journal of Sports Marketing and Sponsorship, 5(1), 24-46. http://dx.doi.org/10.1108/IJSMS-05-01-2003-B003 